\title{
The Study on Effective English Teaching Mode in Vocational and Technical Colleges
}

\author{
YangQing Zhu ${ }^{1}$ \\ ${ }^{1}$ Jiangxi College of Foreign Studies, Nanchang, Jiang Xi, 330038
}

\begin{abstract}
KEYWORDS: Effective English Teaching Mode; Vocational and Technical Colleges
\end{abstract}
\begin{abstract}
In recent years, with the rapid development of higher vocational education, the researchers are paying more attentions to the higher vocational education. Many problems in higher vocational education development have aroused concerns among higher vocational college teachers and researchers. For example, the development the current English teaching in higher vocational colleges is greatly behind the new situation and the new requirements of the society. The higher vocational graduates' English application abilities are not so good, such as, so called "high marks, unintelligence”, “deaf English”. So the effective English teaching in higher vocational colleges are becoming the hot issue.
\end{abstract}

\section{Introduction}

Higher Vocational Education Development of Higher Education as a type of shoulder training for production, construction, services and management of the first line needs highly skilled personnel mission in the promotion of the role of the socialist modernization drive irreplaceable. Of course, it is also faced with serious challenges. The pace of domestic reform and opening up constantly increasing, the community complex talent, especially English-speaking talent demand has undergone tremendous change, increasing demand not only in the number of training, but also in culture and levels of quality are also proposed higher demand, particularly fond of the students' English proficiency. English teaching quality problems have attracted attention. Thus, the effective vocational English teaching has become a hot topic. More and more people began to explore the value and significance of effective teaching. Situation This paper carding system Vocational English teaching, English teaching vocational clear the problems, combined with effective teaching theory, put forward the effect of improving vocational English teaching mode and method, to further explore the development of high effective teaching theory the value and significance of vocational English teaching.

\section{The Concept of Effective Teaching}

Especially effective teaching by regular teachers in the teaching process, the success of cause, maintain and promote student learning, teaching relatively efficiently achieve the desired results of teaching. The so-called "effective", mainly refers to the specific progress or development by teachers after a period of teaching, students receive. That is. Have student progress or development is not the only indicator of teaching effectiveness. There is no teaching effectiveness, does not mean there are no teachers to teach the content or completely taught not serious seriously. But the students have not learned or what students learn better is not good. If a student wants to study or learn, no gain, even if the teachers teach very hard also ineffective teaching. 


\section{Theories and Views of Effective Teaching}

The belief that teaching to build high-performing teachers and students to share what he has personal meaning for him found. Therefore, teachers teach myself and it is difficult to separate. Teaching content and teaching methods are part of the personality of the teacher. No two teachers or two of teaching situations is the same. Therefore, before the others out outstanding teachers teaching model does not necessarily apply to vary teaching environment and individuals. In accordance with the teaching concept of constructivism, the teacher-student interaction, both sides re-build their own understanding of the method to construct all kinds of things and ideas of understanding, but they are also re-builders of mutual understanding. So teachers are required to own method of understanding the world, their concepts of education and teaching methods are more self-awareness.

Whole language teaching theory (Whole language approach), the language as a whole, listening, speaking, reading and writing, is an integral part of organic, not in isolation, these four skills split study. The first principle is that this kind of teaching theory of language teaching should be a holistic approach, and teaches the basics of pronunciation, vocabulary, grammar, and strive to cultivate the skills. The second principle that language knowledge and skills should be fostered by the natural environment and should not be artificially separated language knowledge and skills in isolation culture.

Teachers' implicit theories, that hidden in the hearts of teachers, the theoretical basis of their experience and understanding as well as personal beliefs and personal convictions and principles formed. It is highly personalized theory, a belief in the personal experience of teachers from the self-construction, which is deep-rooted. Teachers' Belief generally is difficult to express in words, but the performance in the teaching operations. Different teaching beliefs can lead to teaching different understanding, different behaviors resulting decisions. Considers that the teaching process is teacher Tuition doubts, or that teaching students self-discovery process discovery, the two different teaching beliefs will inevitably lead to different teaching behavior. Teachers were reflected in the decision-making before class, middle class and after-school activities in a series of three stages. But it is not, in any case before the trailing thinking, but after the side edge line of thinking spontaneously decides to take action, so-called "theory in action."

\section{The Status and Problems of Vocational English Teaching}

With the gradual enrollment of higher vocational colleges in recent years, a surge in the number of students, which makes all faculties in higher vocational colleges, the number of students each class college English classes far exceeds the standard number of language courses. Is no longer the small classes, but "greatly teach classes," the number of students in English classes and some professional University 40-50. The language of this size class, and the students basic English and are "uneven", the instructor is impossible to take into account the differences in level between students; Furthermore, the vast majority of students in higher vocational colleges do not exist in English foundation solid, reading ability is not strong, small vocabulary, listening weak and dumb English and other issues. The previously mentioned most vocational colleges tend to choose teaching undergraduate teaching materials, may be able to take into account a small part of the basis of good students, and most of the English poor foundation, pending through classroom learning English to improve their English proficiency the students were "merciless" objective circumstances neglected.

The current status of vocational English teaching in our country, a classroom teacher is still the main, too much attention to their teachers teach and students learn ignored. Thus they often 
wondered why students in class the dull atmosphere, learning efficiency is not high. Another is derived from students' basic English too weak, some teachers even want to expand the number of classroom interaction in the classroom activities, always feel powerless. Because student participation disappointing. One student foundation is weak, the second is their lack of self-confidence, as well as its participation in the initiative is not high. After several such unsatisfactory classroom interaction, the teacher will feel this too strenuous classroom interaction is also time-consuming, or even affect the completion of the task of teaching. Finally just take the teacher as the main mode of delivery. This teacher as the main mode of delivery will lead to further increases and teaching content, the greater part of the students slowly to keep up with the progress of teaching teachers and depth, which gradually lost interest in learning English, and finally in the classroom that appears inattentive in class, desertion and other phenomena.

Constructive learning is based on learning constructivist learning theory, learning it at the traditional distinction of concern is whether the inherent characteristics of learners. The main characteristics of constructive learning is reflected in the demand for self-learners, to build their own, self-regulation and self-improvement. Learner to make active external information selection and processing, to establish their own sub-tasks included general task, define their problems to be solved, as well as ways and means to achieve each goal. Teachers generally do not directly command learners how to do, but to guide learners to think: you really understand it? There are no loopholes? This interpretation is reasonable? and many more. Finally, constructive learning requires a deep understanding of the formation of knowledge, so that students internal knowledge structure, consolidation of activity, individuality and ability of. But in Vocational English teacher is still the traditional way of teaching, the study merely as knowledge from outside to inside the input process, the learner's task is to collaborate with teachers teaching activities.

Classroom supposed for all students, but in the classroom we often see this phenomenon: teachers for teaching work smoothly, and often few honors or extroverted students dialogue, introverted or poor student achievement in English is difficult to get involved. Teachers accustomed to asking questions to the students to acquire knowledge and interactive case or test students, but the question is often the object of extrovert or a better student achievement. This approach in teaching is better in terms of effectiveness, but will unknowingly give some students an advantage to provide role, causing other students are not confident, thereby unwittingly widened between students English proficiency gap. These students often become teachers overlooked objects. Thus, if the face of all students, introverted or make the basis of poor students to participate in classroom interaction to vocational English teaching is to pay attention to the link.

The relationship between language and social culture of extremely close, language is the carrier of culture, culture is the crystallization of the reflecting mirror of culture; and culture, it restricts the language form, constantly injected into the essence of their language to become the language of performance the basic content. The close relationship between language and social culture determines the close relationship between language teaching and socio-cultural studies in college English teaching classroom, teachers should combine the two, at the same time professor of phonetics, vocabulary, grammar and other linguistic knowledge, culture should be introduced background, combined with social and cultural factors communicative language teaching principles, students use decent language and communicative competence.

\section{Effective Teaching Strategies in Vocational English Teaching}

Flexible use teaching materials, to achieve efficient use of materials and construction Vocational English. From the actual needs of college students, selected practical, with vocational 
characteristics of the new textbook. Content textbooks vocational students should work real life needs, focusing on its usefulness. Teaching materials should fade component vocabulary, grammar basics, and to strengthen the vocational students' English language proficiency (such as English listening, speaking, reading and writing ability) training, vocational training students comprehensive language ability.

Optimization teaching equipment, the popularity of multimedia assisted teaching, realizes the desired effect Vocational English Effective Teaching."Learning English is not an isolated process of learning, in good language learning environment, students more easily and easily learn to master the language and skilled use and master the language." I also hope that the higher vocational colleges to actively use advanced teaching methods aided English Teaching in Higher Vocational English Teaching. For example, you can introduce modern multimedia audio-visual equipment, use some multimedia educational software (such as self-learning software), and secondary school English teaching equipment and so on so that Vocational Training Room English classroom teaching more vivid.

Strengthen the concept of effective vocational English teaching and classroom teaching mode to achieve effective teaching. First, the reform process is to reform teaching methods, teaching reform which is very important step. The first is to change teaching concepts. Effective teaching method first requires teachers in teaching with particular emphasis on guiding students learning methods. Therefore, researchers believe, in teaching, teachers' duties are now less and less knowledge transfer, and more and more excited thinking. Carefully examine the actual needs of students, according to the need to promote and encourage students to learn, thus achieving effective learning.

\section{Conclusion}

In short, effective teaching especially through teacher teaching process regularity, causing success, maintain and promote student learning, teaching relatively efficiently achieve the desired results of teaching. In English teaching, teachers should according to the specific conditions of vocational students in the classroom trying to create an atmosphere for teaching. In this atmosphere, teachers and students always maintain a good teaching and learning attitude. Teachers seriously effectively teach students to actively learn, learn to give, the lingua franca, the formation of a positive interaction with each other.

\section{Reference:}

[1] Ellis. Rod: Second Language Acquisition, Oxford University Press, 1997.

[2] Alessi Stephen $\mathrm{M}$ et Trollip Stanley R. Computer-Based Instruction [M]. Prentice-Hall. Inc.1991.

[3] Pennington M. The Power of CALL [M]. Houston TX. Athelstan, 1996.

[4] Oxford, R. L. \& J Shearin. Language Learning Motivation: Expanding the Theoretical Framework [J], 1994 Modern Language Journal(78):12-28.

[5] Bartlett, L. Teacher Development Through Reflective Teaching (in Richard, J, C. \& Nunan: Second Language Teacher Education), 1990. 